\title{
Rendez-Vous at the Baltic? The Ongoing Dispersion of the Black-Striped Pipefish, Syngnathus abaster
}

\author{
Monteiro $\mathrm{NM}^{1,2^{*}}$ and Vieira $\mathbf{M N}^{3,4}$ \\ ${ }^{1}$ CIBIO, Research Centre in Biodiversity and Genetic Resources, Campus Agrário de Vairão, R. Padre Armando Quintas, 4485-661 Vairão, Portugal \\ ${ }^{2}$ CEBIMED, Faculty of Health Sciences, Fernando Pessoa University, rua Carlos da Maia 296, 4200-150 Porto, Portugal \\ ${ }^{3}$ Faculdade de Ciências da Universidade do Porto, rua do Campo Alegre, 4169-007 Porto, Portugal \\ ${ }^{4}$ CIIMAR/CIMAR, Centro Interdisciplinar de Investigação Marinha e Ambiental, Universidade do Porto, Rua dos Bragas, 289, 4050-123 Porto, Portugal
}

Submission: March 02, 2017; Published: June 28, 2017

*Corresponding author: Monteiro NM, CIBIO, Research Centre in Biodiversity and Genetic Resources, Campus Agrario de Vairão, R Padre Armando Quintas, 4485-661 Vairão, Portugal, Tel: +351252660411; Fax: +351252661780; Email: nm.monteiro@icloud.com

\begin{abstract}
Syngnathus abaster is a pipefish whose distribution is commonly referred as encompassing the Mediterranean and Black Sea, as well as the Atlantic Coast northwards up to the Bay of Biscay. Given the species ability to endure large variation in water salinity, this euryhaline pipefish may now be encountered in a wider variety of aquatic environments, not only marine or brackish but also in purely freshwater habitats. During the last decades, information on the biology of the black-striped pipefish grew, and new data emerged. As this information derives from populations that are geographically distant, it is important to review the available data across the distribution in order to understand the more general processes occurring. While summarizing the distributional information, collected data suggests that $S$. abaster is expanding its spatial distribution in two very distinct ways, either by slowly moving north through the Eastern Atlantic Coast, or by successively establishing viable populations in freshwater ecosystems, in the east. Available data on reproduction suggests that all the sampled populations reproduce at roughly identical temperature ranges, advocating that this species is mainly a spring and summer spawner, at least when inhabiting marine environments. Nevertheless, important inter-populational differences exist in several reproduction-related variables, such as the maximum egg number carried by pregnant males, hinting that the current taxonomy is in need of an extended revision. Open questions related to the causes and implications of freshwater colonization are also further discussed.
\end{abstract}

Keywords: Syngnathus abaster; Distribution; Reproduction; Freshwater expansion; Breeding season

\section{Introduction}

The black-striped pipefish, Syngnathus abaster [1], is a small brown-green syngnathid, with dark or pale spots on the trunk and tail. Adults of both sexes can be easily distinguished by the presence of an inverted brood pouch (marsupium) located in the tail, formed by two skin-folds that contact medially with their free edges. Females lay eggs into the marsupium, where they are fertilised and incubated for about 20-30 days, depending on water temperature. The biogeographic distribution of this pipefish is commonly referred as encompassing the Mediterranean and Black Seas, as well as the Atlantic Coast northwards up to southern Biscay [2]. Nevertheless, given the species ability to endure a large range of salinities, this euryhaline pipefish may now be encountered in a wider variety of aquatic environments, not only marine or brackish but in purely freshwater habitats. In fact, during the last few decades, stable populations of $S$. abaster have been reported inhabiting rivers, such as the Danube, more than $900 \mathrm{~km}$ away from the river mouth $[3,4]$. Interestingly, on the other side of the salinity spectrum, it is also common to observe the black-striped pipefish breeding in reservoirs traditionally used to concentrate water that will ultimately feed salt pans. Altogether, these observations highlight the need for a more up-to-date representation of the species geographical distribution, merging sightings from coastal sites together with the most recent data on freshwater colonisations.

At a micro-geographical scale, at least in coastal areas, $S$. abaster can be found among vegetation, detritus or even sand or mud substrates [2,5]. Nevertheless, a clear preference for sea grass meadows has been generally reported [6-8] where this pipefish tends to occupy a position close to the bottom [6]. In this type of microhabitat, $S$. abaster feeds on small preys hidden 
in the vegetation, sucking them through its cone shaped snout [9-12]. The presence of this pipefish in freshwater habitats seems also to be closely related with vegetated areas, where it tends to occupy the lower part of the channels [13]. Although the conservation status of $S$. abaster is currently catalogued as "Least Concern", according to the IUCN Red List of Threatened Species [14], the close relationship with vegetation, namely sea grass, might explain the steep population decline that can be observed in estuarine areas which are increasingly subjected to strong anthropogenic pressure $[15,16]$.

During the last decade, information on the biology of the black-striped pipefish grew, and new data on the biology of the species emerged. The courtship and mating ritual has been described [17] showing that the general behavioral patterns seem reasonably conserved within the Syngnathidae. Also, the embryonic and larval development was characterized, highlighting the fact that newborn juveniles immediately adopt a benthic distribution [18]. The absence of a pelagic life phase probably has important repercussions in terms of population connectivity given the ongoing fragmentation and degradation of the preferred eelgrass habitat.

A closer analysis of $S$. abaster mating dynamics revealed that this sex-role reversed pipefish tends to mate size-assortatively [19] and that male brooding space did not appear to be the only limitation to female reproduction as neither large nor small individuals presented a fully occupied pouch during the breeding season [20]. Besides revealing a multiple mating strategy and the fact that females do not seem to produce enough eggs to fully occupy a male's brood pouch during the extent of a pregnancy, [21,22] also showed that different-sized individuals adopt different investment tactics, through a continuous scan of the social environment. Temperature fluctuations seem also to play an important role in $S$. abaster reproduction, acting as an effective agent in the modulation of the reproductive behavior, directly affecting sexual recognition, mate preferences and female-female interactions [23]. Given the current climatic changes, the local expression of a species mating system will surely vary [24], with consequences that cannot yet be foreseen given the small amount of information available on estuarine, coastal and freshwater populations.

Although information on S. abaster life history is growing, it is frequently sparse and often times superficial, namely that related to the species life span or reproductive ecology. As an example, for a population inhabiting the brackish bay of the Po river delta [9], authors predicts a life span of approximately 17 months. Full life-cycle aquarium experiments (N. Monteiro, personal observation), conducted with individuals from the Portuguese coast, suggest that the values presented by Freyhof \& Kottelat [25], which mention a life span up to 4 years, might be much more realistic. Large discrepancies exist also on the number of eggs that a male can carry during a pregnancy event. Franzoi et al. [9]. show that males carry on average
109 eggs while data from Atlantic populations reveals a much smaller number of potential offspring (e.g. 69 in the Tagus Estuary). As this information derives from populations that are geographically distant, it seems crucial to review the available data from all across the species distribution, in order to extend our knowledge on the more general processes that might be occurring. This approach could not only allows for a better understanding on general trends versus local adaptations, but also generates a predictive potential able to assess ongoing or future alterations under a climate change scenario. To this extent, this work attempts to summarize the information on the biogeography of the black-striped pipefish, and further extend our knowledge on the species distribution by including the most recent recordings, namely in the European Atlantic coast, as well as in recently colonized freshwater habitats.

\section{Materials and Methods}

Information on the biogeographic distribution of Syngnathus abaster was collected from numerous different source types. Basically, the data presented by Dawson [2] was complemented with information provided by Freyhof \& Kottelat [25]. The distributional area was further extended by the addition of recordings from Belarus [26], the Atlantic coast of France (GBIF Data Portal, data.gbif.org) and Germany (sesam.senckenberg. de). Additionally, apart from the above-mentioned sources, a bibliographic survey was conducted in order to gather sitespecific information on the presence of $S$. abaster and, when possible, data on the species reproductive season and migratory vs. resident behavior. Given that this species has numerous synonyms, some still recurrently found in the literature, the survey was conducted also using the terms $S$. algeriensis, $S$. agassizii or $S$. nigrolineatus. The summary of the obtained data was plotted in, based on the following information (here discriminated by country): Portugal [27-32]; Spain [33,34]; France [35-37]; Italy [5,6,8-10,38-43]; Croatia [44]; Serbia [4]; Greece [38,45,46]; Turkey [47,48]; Bulgaria [49]; Ukraine [4,13,50]; Belarus [26]; Russian Federation [13,51,52]; Iran [5355]; Egypt [38]; Tunisia [1,56]; and Algeria [57].

In order to construct a more general view of $S$. abaster reproductive season across the species' geographical distribution see Table 1, the information available in the literature was used Portugal [27]; Spain [33]; France [36]; Italy [9,10,41]; Greece $[45,54]$. New data is provided for Aveiro, Portugal $\left(40^{\circ} 38^{\prime} \mathrm{N}\right.$, $8^{\circ} 39^{\prime} \mathrm{W}$ ).

\section{Results}

What seems to be the most up-to-date map of Syngnathus abaster distribution is depicted in Figure 1. The distribution presented by [2] had already been considerable extended by [25], mainly by the inclusion of the Caspian Sea, Sea of Azov, and freshwater locations (e.g. Danube, Dnieper, Don and Volga). The presence of the black-striped pipefish in these locations was confirmed, following a literature review, (Figure 1: b/w squares). 
Additionally, the presence in Rybinskoye Reservoir (Russia) was also validated through an in-situ observation (S. Drovetsky, personal observation). A northwards colonization of the Dnieper seems to be occurring, as $S$. abaster is now present in Belarus) [26]. In the European Atlantic Coast, new observations exist northwards of Biscay, the reported northern limit of distribution in the Atlantic. These new locations, both in France and Germany, if further validated through repeated observations, suggest a rapid colonisation of the Atlantic up to the Baltic Sea.

In Aveiro (Portugal), the breeding season of S. abaster occurs from March to September [19]. Sampling campaigns conducted outside the breeding season, that included the trawling of several locations within this estuarine lagoon, did not allow the capture of any individual. These observations suggest that this pipefish uses this specific location as a reproduction area, abandoning the area at the end of the breeding season. This data, when integrated with that already available for other locations (see Figure 1) suggests that the breeding season occurs generally from March to October (Table 1), probably dependent on the

Table 1: The extent of S. abaster breeding season across the species geographical distribution.

\begin{tabular}{|c|c|c|c|c|c|c|c|c|c|c|c|c|c|}
\hline Country & Location & Jan & Feb & Mar & Apr & May & Jun & Jul & Aug & Sep & Oct & Nov & Dec \\
\hline Portugal & Aveiro & & & $*$ & $*$ & $*$ & $*$ & $*$ & $*$ & $*$ & & \\
\hline Portugal & Tagus Estuary & & & $*$ & $*$ & $*$ & $*$ & $*$ & $*$ & $*$ & $*$ & & \\
\hline Spain & Fornells Bay & & & $*$ & $*$ & $*$ & $*$ & $*$ & $*$ & $*$ & $*$ & & \\
\hline France & Mauguio Lagoon & & & $*$ & $*$ & $*$ & $*$ & $*$ & $*$ & $*$ & $*$ & \\
\hline Italy & Stagnone Lagoon & & & $*$ & $*$ & $*$ & $*$ & $*$ & $*$ & $*$ & $*$ & & \\
\hline Italy & Po River Delta & & & $*$ & $*$ & $*$ & $*$ & $*$ & & & & & \\
\hline Italy & Venice lagoon & & & & $*$ & $*$ & $*$ & $*$ & $*$ & $*$ & $*$ & & $*$ \\
\hline Greece & Strymonikos Gulf & & $*$ & $?$ & $?$ & $?$ & $?$ & $?$ & $*$ & $*$ & $*$ & & \\
\hline Iran & South Caspian Sea & & & & & $*$ & $?$ & $*$ & $?$ & $*$ & & & \\
\hline
\end{tabular}

When looking at the maximum number of eggs present in pregnant males, large discrepancies are observed. While in Portugal (53 eggs recorded during the 2010 field season) and France 52 eggs; [36] the reported values are similar, the maximum number of eggs reported for the Italian populations, in the Adriatic area $[9,41]$, are clearly much higher (Venice, 122 eggs; Po River Delta, 136 eggs).

\section{Discussion}

Syngnathus abaster has been traditionally viewed as a Mediterranean pipefish, as the main bulks of observations were concentrated in this area, although it has been reported also in the Black Sea and throughout the Iberian Peninsula Coast [see 2]. More recent data, however, suggest that this species has greatly increased its distribution, in two very distinct manners occurring in geographically opposite locations:

-Firstly, by expanding its northern limit of distribution in the Atlantic coast, surpassing the Bay of Biscay, towards the Baltic Sea. If the collected observations are further corroborated by additional captures, it suggests a pattern of colonization consistent with what is currently being observed with other warmer water temperatures.

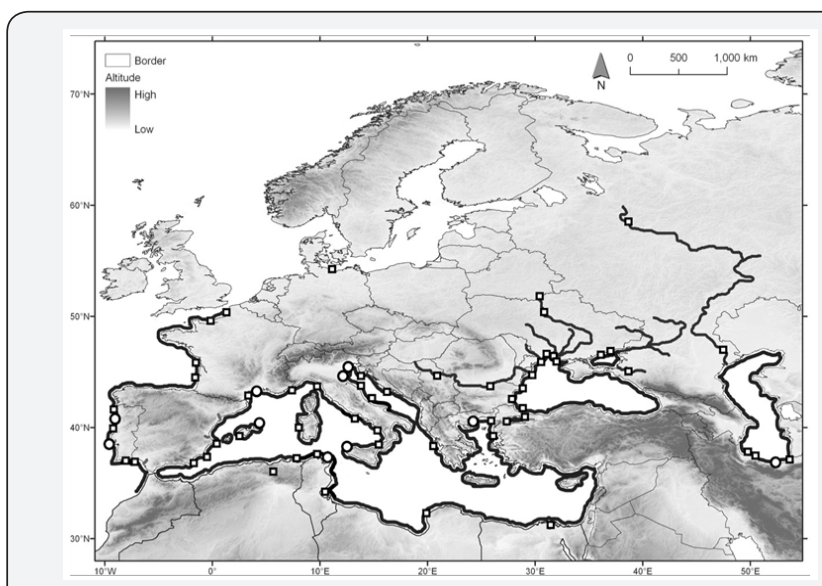

Figure 1: The biogeographical distribution of Syngnathus abaster (b/w squares depict locations from where there is a confirmation of presence; b/w circles indicate locations from which there is information on both presence and reproduction). warm-water species whose northern limit of distribution is moving polewards [58-60], probably as a consequence of climate change see [61]. If this rapid colonization of the Atlantic is indeed taking place, as evidence suggests, the monitoring of the reproductive ecology of Atlantic populations gains a renewed importance as it can potentially provide new insights on previously undescribed adaptive responses exhibited by this pipefish.

-And secondly, by establishing viable populations in freshwater ecosystems in the eastern part of the species' distribution. A closer inspection of Figure 1 immediately generates an inescapable question: Why has this freshwater colonisation occurred only in the eastern part of the distribution, when there are rivers in the West as well? The simplest explanation to this phenomenon might just be that this freshwater invasion is a result of anthropogenic action rather than an active migration performed by this pipefish. If fish indeed actively colonised freshwater environments, there were no obvious reasons that obstructed their presence in rivers that flowed into more western sections of the Mediterranean. If, on the other hand, S. abaster, is being introduced into freshwater 
ecosystems, then it could be hypothesised that rivers large enough to harbour ship traffic are more prone to receive these guests from marine or brackish areas. With the exception of the Rhone, large enough rivers able to accommodate high levels of traffic (such as the Loire, Seine, Loire or Rhine) do not flow into the Mediterranean in its western section. Such rivers do exist in the east, however, and they all seem to be recently colonized by S. abaster (e.g. Danube, Dnieper, Don or Volga). Indeed, Semenchenko \& Cakic et al. [4,26] state that commercial ships acted as vectors, probably through ship ballast-water. The presence of the black-striped pipefish in water reservoirs could also be due to accidental introductions, as seems to have occurred in middle and lower Volga region, where these fish where brought together with mysids from the Don estuary [52]. The existence of dams, for instance, probably eased the establishment of freshwater $S$. abaster populations by creating more favourable hydrodynamic conditions.

The Mediterranean populations from where data exists on the timing of the breeding season all seem to reproduce at roughly identical temperature ranges, suggesting that this species is mainly a spring and summer spawner. But, when observing the distributional data, it seems obvious that freshwater populations are subjected to very distinct temperature regimes. This fact raises several interesting questions, such as when and how breeding takes place in these cooler locations, thus reinforcing the need for more complete sampling campaigns all over the species distribution [62].

Even within the Mediterranean basin, there seem to exist important differences among populations in several reproduction related variables, either behavioral (there are resident populations that inhabit a certain location throughout the year while in other places individuals migrate to coastal areas to breed) or morphological/physiological (the maximum number of eggs that is dependent on either male/marsupium size, egg size or a combination of both, greatly varies in certain locations). A thorough molecular analysis will surely help answer many of the questions that still persist such as the most basic one: are we really talking about just one species.

\section{References}

1. Ben Amor MM, Ben Salem M, Ben Souissi J, Capape C (2006) Observations on the black-striped pipefish Syngnathus abaster Risso 1826 (Syngnathidae) from Tunisian waters (Central Mediterranean). Annales, Series Historia Naturalis 16: 193-198.

2. Dawson CE (1986) Syngnathidae. In: PJP Whitehead (Ed.), Fishes of the north-eastern Atlantic and the Mediterranean. Unesco, Paris, France, pp. 628-639.

3. Sekulicc N, Cakicc P, Lenhardt M, Vucicc D, Budakov LJ (1999) Shortsnouted pipefish Syngnathus abaster (Acanthopterygii: Syngnathidae) in Yugoslav section of the Danube. Ichthyologia 3: 79-82.

4. Cakic P, Lenhardt M, Mickovic D, Sekulıc N, Budakov LJ (2002) Biometric Analysis of Syngnathus abaster populations. Journal of Fish Biology 60(6): 1562-1569.
5. Franco A, Franzoi P, Malavasi S, Riccato F, Torricelli P, et al. (2006) Use of shallow water habitats by fish assemblages in a Mediterranean coastal lagoon. Estuarine Coastal and Shelf Science 66: 67-83.

6. Malavasi S, Franco A, Riccato F, Valerio C, Torricelli P, et al. (2007) Habitat selection and spatial segregation in three pipefish species. Estuarine, Coastal and Shelf Science 75: 143-150.

7. Cubedo VD, Oliva Paterna J, Forero TM (2007) Fish assemblages associated with Cymodocea nodosa and Caulerpa prolifera in the shallow areas of the Mar Menor coastal lagoon. Limnetica 26(2): 341350 .

8. Manzo C (2010) Fish assemblages in three Mediterranean coastal lagoons: Structure, functioning and spatio-temporal dynamics. $\mathrm{PhD}$ Thesis, Università degli studi di Roma Tor vergata, Facoltà di Scienze matematiche, Fisiche e Naturali pp.105.

9. Franzoi P, Maccagnani R, Rossi R, Ceccherelli VU (1993) Life cycles and feeding habits of Syngnathus taenionotus and S. abaster (Pisces, Syngnathidae) in a brackish bay of the Po River Delta (Adriatic Sea). Marine Ecology Progress Series 97: 71-81.

10. Campolmi M, Franzoi P, Mazzola A (1996) Observations on pipefish (Syngnathidae) biology in the Stagnone lagoon (west Sicily). Publicaciones especiales del Instituto Espanol de Oceanografia 21: 205-209.

11. Kendrick AJ, Hyndes GA (2005) Variations in the dietary compositions of morphologically diverse syngnathid fishes. Environmental Biology of Fishes 72: 415-427.

12. Mouillot D, Dumay O, Tomasini JA (2007) Limiting similarity, niche filtering and functional diversity in coastal lagoon fish communities. Estuarine, Coastal and Shelf Science 71: 443-456.

13. Vasileva ED (2003) Main alterations in ichthyofauna of the largest rivers of the northern coast of the Black Sea in the last 50 years: A review. Folia Zoologica 52: 337-358.

\section{IUCN (2008) IUCN Red List of Threatened Species.}

15. Pombo L, Elliott M, Rebelo JE (2002) Changes in the fish fauna of the Ria de Aveiro estuarine lagoon (Portugal) during the twentieth century. Journal of Fish Biology 61: 167-181.

16. Pombo LM, Rebelo JE (2002) Spatial and temporal organization of a coastal lagoon fish community: Ria de Aveiro, Portugal, Cybium. The European Journal of Ichthyology 26: 185-196.

17. Silva K, Monteiro NM, Vieira MN, Almada VC (2006) Reproductive behaviour of the black-striped pipefish, Syngnathus abaster (Pisces; Syngnathidae). Journal of Fish Biology 69: 1860-1869.

18. Silva K, Monteiro NM, Almada VC, Vieira MN (2006) Early life history of Syngnathus abaster (Pisces: syngnathidae). Journal of Fish Biology 68: 80-86

19. Cunha M, Berglund A, Monteiro NM (2015) The intrinsically dynamic nature of mating patterns and sexual selection. Environmental Biology of Fishes 98(4): 1047-1058.

20. Silva K, Vieira MN, Almada VC, Monteiro NM (2008) Can the limited marsupium space be a limiting factor for Syngnathus abaster females: insights from a population with size assortative mating. J Anim Ecol 77(2): 390-394.

21. Silva K, Almada VC, Vieira MN, Monteiro NM (2009) Female reproductive tactics in a sex-role reversed pipefish: scanning for male quality and number. Behavioural Ecology 20: 768-772.

22. Silva K, Vieira MN, Almada VC, Monteiro NM (2010) Reversing sex-role reversal: scanning for quality and number. Animal Behaviour 79: 885893. 
23. Silva K, Vieira MN, Almada VC, Monteiro NM (2007) The effect of temperature on mate preferences and female-female interactions in Syngnathus abaster. Animal Behaviour 74: 1525-1533.

24. Monteiro N, Cunha M, Ferreira L, Vieira N, Antunes A, et al. (2017) Parabolic variation in sexual selection intensity across the range of a cold-water pipefish: implications for susceptibility to climate change. Glob Change Biol doi: 10.1111/gcb.13630.

25. Freyhof J, Kottelat M (2008) Syngnathus abaster. In: IUCN 2010. IUCN Red List of Threatened Species. Version 2010.3.

26. Semenchenko VP, Rizevsky VK, Mastitsky SE, Vezhnovets VV, Pluta MV, et al. (2009) Checklist of aquatic alien species established in large river basins of Belarus. Aquatic Invasions 4: 337-347.

27. Marques JM (1990) Contributos para o conhecimento da biologia, ecologia esistemática dos Syngnathidae(Pisces) (Estuario do Tejo): uma perspectiva ecotoxicológica. Relatório de estágio profissionalizante na Licenciatura de Recursos Faunísticos e Ambiente. Lisboa: Faculdade de Ciencias da Universidade de Lisboa pp. 279.

28. Re P (1999) Ictioplâncton estuarino da península Ibérica (Guia de Identificação dos ovos e estados larvares planctônicos). Lisboa, pp. 141.

29. Faria A, Moraisa P, Chícharo MA (2006) Ichthyoplankton dynamics in the Guadiana estuary and adjacent coastal area, South-East Portugal Estuarine, Coastal and Shelf Science 70: 85-97.

30. Ramos S, Robert KC, Paris C, Re P, Bordalo AA (2006) Environmental forcing and larval fish assemblage dynamics in the Lima River estuary (northwest Portugal). Journal of Plankton Research 28(3): 275-286.

31. Oliveira F, Erzini K, Gonçalves J (2007) Feeding habits of the deepsnouted pipefish Syngnathus typhle in a temperate coastal lagoon. Estuarine, Coastal and Shelf Science 72: 337-347.

32. Oliva Paterna FJ, Andreu A, Miñano PA, Verdiell D, Caballero A, et al (2003) Ictiofauna de zonas someras del Mar Menor (SE Península Ibérica): Especies con presencia de alevines y juveniles. Anales de Biología 25: 206-208.

33. Manent P, Abella J (2004) Aspectos ecológicos y biológicos de Syngnathus abaster Risso, 1826, en la bahía de Fornells. Revista de Menorca 88.

34. Pérez-Ruzafa A, García-Charton JA, Barcala E, Marcos C (2006) Changes in benthic fish assemblages as a consequence of coastal works in a coastal lagoon: The Mar Menor (Spain, Western Mediterranean). Mar Pollut Bull 53(1-4): 107-120.

35. Quignard JP, Mazoyer C, Vianet R, Manwai R, Benharrat IC (1983) Un exemple d'exploitation lagunaire en Languedoc: l'étang de l'Or (Mauguio). Pêche et production halieutique. Science et Pêche, Bulletin de Institute des Pêches Maritimes 336: 3-23.

36. Tomasini JA, Quignard CP, Capapé C, Bouchereau JL (1991) Facteurs du succèss reproductif de Syngnathus abaster Risso, 1826 (Pisces, Teleostei, Syngnathidae) en milieu lagunaire me̋diterrane̋en (lagune de Mauguio, France). Acta OEcologica 12: 331-355.

37. Carlier A, Riera P, Amouroux JM, Bodiou JY, Escoubeyrou K, et al. (2007) A seasonal survey of the food web in the Lapalme Lagoon (northwestern Mediterranean) assessed by carbon and nitrogen stable isotope analysis. Estuarine, Coastal and Shelf Science 73: 299-315.

38. Ancona U (1933) Il Syngnathus algeriensis Playfair e le forme mediterranee affini de gen. Syngnathus. Italian Journal of Zoology 4: 107-115.

39. Tortonese E (1970) Fauna d'Italia. Osteichtyes (Pesci ossei), Parte prima 10. Edizioni Calderini, Bologna, pp. 442-468.

40. Franzoi P, Di Filippo C, Bruno MC, Rossi R (1997) Ritmo nictemerale di alimentazione di Syngnathus taenionotus e S. abaster (Osteichthyes,
Syngnathidae) in una laguna del delta del Po. Biologia Marina Mediterranea 4: 521-524.

41. Malavasi S, Fiorin R, Franco A, Franzoi P, Granzotto A, et al. (2004) Fish assemblages of Venice Lagoon shallow waters: an analysis based on species, families and functional guilds. Journal of Marine Systems 51: 19-31.

42. Sanna D, Addis A, Biagi F, Motzo C, Carcupino M, et al. (2008) mtDNA control region and D-HPLC analysis: a method to evaluate the mating system in Syngnathidae (Teleostei). Marine Biology 153(3): 269-275.

43. Dulcic J, Matic Skoko S, Kraljevic M, Fencil M, Encil M, et al. (2005) Seasonality of a fish assemblage in shallow waters of Duce-Glava, eastern middle Adriatic. Cybium 29: 57-63.

44. Koutrakis E, Sylaios G, Kamidis N, Markou D, Sapounidis A (2009) Fish fauna recovery in a newly re-flooded Mediterranean coastal lagoon. Estuarine, Coastal and Shelf Science 83(4): 505-515.

45. Gurkan S (2008) The biometric analysis of pipefish species from Çamaltı Lagoon (İzmir Bay, Aegean Sea) EU Journal of Fisheries and Aquatic Sciences 25(1): 53-56.

46. Özuluğ M (2008) The fish fauna of the Durusu Lake Basin (IstanbulTurkey). IUFS Journal of Biology 67: 73-79.

47. Stefanov T (2007) Fauna and Distribution of Fishes in Bulgaria in Biogeography and Ecology of Bulgaria. Monographiae Biologicae 82: 109-140.

48. Luzhnyak VA, Korneev AA (2006) Modern ichthyofauna of the Lower Don Basin in conditions of the anthropogenic transformation of its runoff. Journal of Ichthyology 46(7): 525-533.

49. Bogutskaya NG, Naseka AM (2002) An overview of nonindigenous fishes in inland waters of Russia. Proceedings of the Zoological Institute of the Russian Academy of Sciences 296: 21-30.

50. Ermolin VP (2010) Composition of the Ichthyofauna of the Saratov Reservoir. Journal of Ichthyology 50: 211-215.

51. Paateemaar R (1993) Pipefish of the Caspian Sea. Abzeeyan, Tehran 4: $20-23$.

52. Coad BW (2002) Freshwater Fishes of Iran.

53. Patimar R, Najafabadi MH, Souraki MG (2010) Life history features of the nonindigenous three-spined stickleback (Gasterosteus aculeatus Linnaeus, 1758) in the Gomishan wetland (southeast Caspian Sea, Iran). Turkish Journal of Zoology 34: 461-470.

54. Chaouachi B, Hassine OKB (1998) The status of fish biodiversity in Ichkeul Lagoon, Tunisia. Italian Journal of Zoology 65: 303-304.

55. Chaoui LL, Kara MH, Faure E, Quignard JP (2006) Lichtyofaune de la lagune du Mellah (Algérie Nord-Est): diversité, production et analyse des captures commerciales. Cybium 30(2): 123-132.

56. Stebbing ARD, Turk SMT, Wheeler A, Clark KR (2002) Immigration of southern fish species to southwest England linked to warming of the North Atlantic (1960-2001). Journal of the Marine Biological Association of the UK 82(2): 177-180.

57. Perry AL, Low PJ, Ellis JR, Reynolds JD (2005) Climate change and distribution shifts in marine fishes. Science 308: 1912-1915.

58. Poulard JC, Blanchard F (2005) The impact of climate change on the fish community structure of the eastern continental shelf of the Bay of Biscay. ICES Journal of Marine Science 62(7): 1436-1443.

59. Parmesan C, Yohe G (2003) A globally coherent fingerprint of climate change impacts across natural systems. Nature 421: 37-42.

60. Muséum national d'Histoire naturelle (2003-2010) Inventaire national du Patrimoine naturel. 
61. Koutrakis E, Kokkinakis AA, Eleftheriadis EA, Argyropoulou MD (2000) Seasonal changes in distribution and abundance of the fish fauna in the two estuarine systems of Strymonikos Gulf (Macedonia, Greece). Belg J Zool 130: 43-50.

his work is licensed under Creative

Commons Attribution 4.0 Licens

DOI: 10.19080/OFOAJ.2017.03.555608
62. Riccato F, Fiorin R, Franco A, Franzoi P, Libertini A, et al. (2003) Population structure and reproduction of three pipefish species (Telostei, Syngnathidae) in a seagrass meadow of the Venice Lagoon. Biol Mar Medit 10(2): 138-145.

\section{Your next submission with Juniper Publishers will reach you the below assets}

- Quality Editorial service

- Swift Peer Review

- Reprints availability

- E-prints Service

- Manuscript Podcast for convenient understanding

- Global attainment for your research

- Manuscript accessibility in different formats ( Pdf, E-pub, Full Text, Audio)

- Unceasing customer service

Track the below URL for one-step submission https://juniperpublishers.com/online-submission.php 